\title{
Does Islam Fuel Antisemitism?
}

Quotations can always be taken out of context, and the words of any given leader do not necessarily represent the views of his or her followers. Nonetheless, it can be useful to hear what a few admittedly extreme Muslim leaders have been saying about Jews recently. Consider, for example, how the Sudanese Imam Mohamed Abdul-Kareem responded in February, 2017, to a call for normalization of relations with Israel. "The Muslims' enmity toward the Jews," he suggested,

stems from their very belief in Allah. The belief in Allah makes it imperative for the Muslims never to refrain from feeling and evoking enmity toward the slayers of the prophets, towards the brothers of apes and pigs ... How can a Muslim possibly reach out to a people who were cursed by Allah and who incurred his wrath?

The imam then made clear the extent of his disagreement with Yousuf Al-Koda, the Sudanese sheikh who had proposed better relations with Israel: "Whoever strives to remove the enmity and hatred between the Muslims and the Jews is a heretic and apostate, who has renounced Islam."1

Several months later, Saudi Sheikh Mamdouh Al-Harbi concurred that contemporary political disagreements do not lie at the root of Muslim anger toward Jews: "Anyone who claims that our war is with the Zionists rather than the Jews is mistaken. This constitutes a denial of the words of Allah and of the Prophet Muhammad."2 Also in 2017, across the world in Jersey City, New Jersey, Imam Aymen Elkasaby declared:

So long as the Al-Aqsa Mosque remains prisoner in the hands of the Jews, this nation [the Muslim nation] will remain humiliated. So long as the Al-Aqsa Mosque remains under the

\footnotetext{
Note: The author would like to thank Nora May McSorley of Columbia University for her assistance with this paper. An earlier version of this paper was presented under the title, "Assessing the Role of Islam in the Creation and Maintenance of Antisemitism in Muslim Communities around the World" at "An End to Antisemitism!" International Conference, February 12, 2018, University of Vienna, Vienna, Austria
}

1 "Sudanese Imam Responds to Call for Normalization of Ties with Israel," MEMRI TV clip no. 5949, February 16, 2017, https://www.memri.org/tv/sudanese-imam-responds-call-normal ization-ties-israel-muslims-enmity-towards-brothers-pigs-and.

2 “Saudi Cleric Mamdouh Al-Harbi: Muslims' War Is with the Jews, Not Just Zionists," MEMRI TV clip no. 6162, July 26, 2017, https://www.memri.org/tv/saudi-cleric-muslim-war-with-jews-notjust-zionists.

Ә OpenAccess. () 2022 Neil J. Kressel, published by De Gruyter. (cc) BY-NC-ND This work is licensed under the Creative Commons Attribution-NonCommercial-NoDerivatives 4.0 International License. 
feet of the apes and pigs, this nation will remain humiliated ... Oh Allah, bring Al-Aqsa back into the fold of Islam and the Muslims. . . Count them [the Jews] one by one, and kill them down to the very last one. Do not leave a single one on the face of the Earth. ${ }^{3}$

Finally, numerous times in the past few years, Islamic religious and political leaders have made reference to one particular hadith, or saying, attributed to the Prophet Muhammad. In July 2017, Ammar Shahin-a California imamsermonized:

The Prophet Muhammad said: "Judgment Day will not come until the Muslims fight the Jews, and the Jews hide behind stones and trees, and the stones and the trees say: Oh Muslim, oh servant of Allah...” They will not say: Oh Egyptian, oh Palestinian, oh Jordanian, oh Syrian, oh Afghan, oh Pakistani. The Prophet Muhammad says that the time will come; the Last Hour will not take place, until the Muslims fight the Jews. We don't say if it is in Palestine or another place. . . When that war breaks out, they [the Jews] will run and hide behind every rock, and house, and wall, and trees. The house, the wall, and the trees will call upon the Muslims: ... "Come, there is someone behind me-except for the Gharqad tree, which is the tree of the Jews. . . . That's the tree that will not speak to the Muslims."

The same hadith appeared in a lecture by Syrian Imam Abdullah Khadra in Raleigh, North Carolina, and it was featured by Jordanian Sheikh Muhammad Bin Musa Al-Nasr in a December, 2016, sermon in Montreal, Canada. ${ }^{5}$ Yet again, and not surprisingly, the hadith animated Hamas legislator Marwan Abu Ras's sermon in January, 2017. The reason his allusion to the hadith is not surprising, of course, is because until recently, it was a part of the official Hamas Charter. Marwan Abu Ras's conclusion was, arguably, genocidal:

3 Quoted in “Friday Sermon at Jersey City, NJ,” MEMRI TV clip no. 6310, December 8, 2017. Retrieved from https://www.memri.org/tv/antisemitic-sermon-jersey-city-imam-aymen-elkasaby, (accessed July 30, 2018).

4 "California Friday Sermon: Imam Ammar Shahin Cites Antisemitic Hadith, Prays for Annihilation of Jews, and Calls to Liberate Al-Aqsa Mosque from Their 'Filth'," MEMRI TV clip no. 6133, July 21, 2017, https://www.memri.org/tv/california-sermon-antisemitic-sermon-kill-jews-liberateal-aqsa-mosque.

5 "Friday Sermon in the Raleigh Area, NC, by Syrian Imam Abdullah Khadra," MEMRI TV clip no. 6310, December 8, 2017, https://www.memri.org/tv/antisemitic-sermon-jersey-city-imamaymen-elkasaby; Al-Nasr quoted in A. Pink, "Arrest Warrant Issued for Imam who Called for Jews to be Killed,” Forward, July 16, 2017, https://forward.com/fast-forward/377144/arrest-war rant-issued-for-imam-who-called-for-jews-to-be-killed/. 
Oh Allah, show us the black day that you inflict upon them, and the wonders of your ability. Oh Allah, count them one by one and annihilate them down to the very last one. Do not spare any of them. ${ }^{6}$

Needless to say, the religious leaders quoted above are extremists. None of them represents the views of moderate Muslims, and while their expressed opinions should not be described as rare in the Muslim world, neither can they be called mainstream. Sometimes, the people who say these sorts of things end up apologizing under pressure or, less often, are fired-especially in the United States. Occasionally, organizations like CAIR-the Council on American-Islamic Relations-denounce them.

Moreover, we cannot assume that these extremists' attribution of their own current attitudes toward Jews to ancient religious sources is either scientifically accurate or theologically sound. Marwan Abu Ras, the Hamas politician, certainly sounds like his hatred is religiously inspired. Yet he also declares:

Oh criminal Jews, Allah described your characteristics to us. You cannot remain on our land! We shall never relinquish a single inch of our land. . . [The Jewish enemy] sends AIDS-infected girls to fornicate with Muslim youths, in order to spread fornication and AIDS among Muslim youth. . .

Such paranoia, intransigence, and hostility are hardly a cause for hope; they may, however, suggest that there are political, sociological, and psychological foundations for Marwan Abu Ras's antisemitism. Plenty of antisemitic quotations in the Muslim world, after all, sound like they might have been lifted from the Nazis or from The Protocols of the Elders of Zion-both European imports having nothing to tie them directly to Islam. The religion may or may not be a central cause of Marwan Abu Ras's hatred; he, arguably, may be using the language of the past to provide a prose background for hostility which, in actuality, has more proximal causes. Some Muslim thinkers have argued that the hadith about killing Jews to bring about end times has been unjustifiably appropriated by Jew-haters and that benign interpretations of this hadith are plausible. ${ }^{8}$ This may seem like a stretch but the matter is, in the final anal-

6 “Gaza Friday Sermon by Hamas MP Marwan Abu Ras," MEMRI TV clip no. 5846, January 6, 2017, https://www.memri.org/tv/gaza-friday-sermon-hamas-mp-marwan-abu-ras-jews-recruitprostitutes-girls-aids-lure-arabs-their.

7 Ibid.

8 Yaqeen Institute for Islamic Research, "The Hadith And The Myth Of An Antisemitic Genocide In Muslim Scripture,” Huffington Post, March 28, 2017, https://www.huffingtonpost.com/entry/ the-jew-killing-hadith-and-the-myth-of-an-antisemitic_us_58da7e56e4b0e96354656eb6. 
ysis, for Muslim scholars to decide. In any case, progressive Muslims may seek and, possibly, find theologically acceptable methods of defanging antisemitic hadiths that are genuinely rife with antisemitic potential. ${ }^{9}$

Nonetheless, a large enough number of Muslim religious leaders have identified a vast number of religious sources for their hostility, enough to make a potentially refutable prima facie case that source material in the Islamic tradition predisposes contemporary Muslims to anti-Jewish bigotry. But it is a complicated matter to determine precisely how-and to what extent-contemporary Muslim antisemitism can be described as Islamic, or religious, in origin. That such antisemitism prevails in many parts of the Muslim world, however, is far less subject to debate among reasonable people.

\section{The Prevalence of Antisemitism in the Muslim World}

Few realms of scholarly debate these days seem less likely to turn on careful collection of scientific data than those involving bigotry, religion, Jews, Muslims, and the Middle East. Yet, for those who care to look, a great deal of empirical evidence documents substantial anti-Jewish hatred in much of the Muslim world. While the style, intensity, and extent of this bigotry vary by region, country, political ideology, religiosity, and other dimensions, the overall antisemitic movement seems undeniably widespread. Scholars who have studied Muslim antisemitism have concluded that it is currently growing and dangerous. ${ }^{10}$

Unfortunately, for a variety of reasons (which I have addressed elsewhere), most experts on the Middle East and most "anti-racists" in government, academ-

9 T. Fatah, The Jew is Not My Enemy: Unveiling the Myths that Fuel Muslim Anti-Semitism (Plattsburgh: McClelland \& Stewart, 2011), 103-29.

10 R. N. Bali, "Conspiracy Theories, Antisemitism and Jews in Turkey Today," in Global Antisemitism: A Crisis of Modernity, ed. C. A. Small (New York: ISGAP, 2013); A. G. Bostom, The Legacy of Islamic Antisemitism: From Sacred Texts to Solemn History (Amherst: Prometheus Books, 2008); A. G. Bostom, Iran's Final Solution for Israel: The Legacy of Jihad and Shi'ite Islamic Jew-Hatred in Iran (Washington: Bravura Books, 2014); Fatah, The Jew Is Not My Enemy; R. Jaspal, Antisemitism and Anti-Zionism: Representation, Cognition, and Everyday Talk (Farnham: Ashgate, 2014); G. Jikeli, European Muslim Antisemitism: Why Young Urban Males Say They Don't Like Jews (Bloomington: Indiana University Press, 2015); N. J. Kressel, “The Sons of Pigs and Apes": Muslim Antisemitism and the Conspiracy of Silence (Washington: Potomac, 2012); R. S. Wistrich, A Lethal Obsession: Anti-Semitism from Antiquity to the Global Jihad (New York: Random House, 2010). 
ia, and the human rights community have shown either an unfortunate blindness to the problem or a willingness to explain it away as insignificant or otherwise unworthy of attention. ${ }^{11}$ Some social scientists have objected to the way antisemitism has been operationalized in studies, while others have argued that antisemitic attitudes really tap hostility toward Israel. ${ }^{12}$ Yet even among those relatively few journalists, scholars, and activists who are keenly aware of current antisemitism in Muslim communities, there remains considerable confusion, disagreement, and debate about the sense in which this bigotry can be described as "Islamic." Most controversial has been the question of whether Islamic religious beliefs, practices, and traditions might in some sense-perhaps a crucial sensebe responsible for (or contribute to) the creation and maintenance of antisemitism.

The possibility of linkage between religion and prejudice has been a major topic of interest for psychologists of religion at least since Gordon Allport highlighted the relationship between measures of Christian religiosity and some types of bigotry in his seminal 1954 volume, The Nature of Prejudice. ${ }^{13}$ As recent reviews of studies in the psychology of religion have noted, research on religion and prejudice overwhelmingly has dealt with Christian attitudes toward various minorities, frequently focusing on Blacks and the LGBTIQ+ community but also, occasionally, including Jews-as for example, in Charles Glock and Rodney Stark's (1966) classic, Christian Beliefs and Anti-Semitism. ${ }^{14}$ Psychologists of religion have devoted great effort to understanding which aspects of Christianity

11 N. J. Kressel, "The Great Failure of the Anti-Racist Community: The Neglect of Muslim Antisemitism in English-language Courses, Textbooks, and Research," in From Antisemitism to AntiZionism: The Past and Present of a Lethal Ideology, ed. E. G. Pollack (Boston: Academic Studies, 2017), 29. See, also, B. Harrison, The Resurgence of Anti-Semitism: Jews, Israel, and Liberal Opinion (Lanham: Rowman \& Littlefield, 2006); N. Cohen, What's Left?: How Liberals Lost Their Way (New York: Harper Perennial, 2007); D. Hirsh, "Anti-Zionism and Antisemitism: Cosmopolitan Reflections," in The Yale Papers: Antisemitism in Comparative Perspective, ed. C. A. Small (New York: ISGAP, 2015), 57-174.

12 See, for example, M. Bunzl, Anti-Semitism and Islamophobia: Hatreds Old and New in Europe (Chicago: Prickly Paradigm, 2007); J. J. Mearsheimer and S. M. Walt, The Israel Lobby and U.S. Foreign Policy (New York: Farrar, Straus and Giroux, 2008); J. Cohen, "The Accusation of AntiSemitism as Moral Blackmail," Human Architecture (2009): 23-33; J. Butler, "Foreword," in On Anti-Semitism: Solidarity and the Struggle for Justice, ed. Jewish Voice for Peace (Chicago: Haymarket Books: 2017), vii.

13 G. W. Allport, The Nature of Prejudice (New York: Addison-Wesley, 1979), 444-57. See, also, G. W. Allport and J. M. Ross, "Personal Religious Orientation and Prejudice," Journal of Personality and Social Psychology (1967): 432.

14 C. Y. Glock and R. Stark, Christian Beliefs and Anti-Semitism (New York: Harper \& Row, 1966). 
and which orientations to religion (intrinsic, extrinsic, quest, etc.) do and do not encourage bigotry of various types. ${ }^{15}$

Very little research by psychologists has examined the relationship between Islamic religious beliefs and anti-Jewish prejudice. Social scientists' relative neglect of Muslim antisemitism was recently documented in an empirical content analytic study of items listed in four huge social science databases: PSYCHINFO, Sociological Abstracts, ProQuest Social Science Journals, and Worldwide Political Science Abstracts. ${ }^{16}$ Database searches went up to the end of 2014, though the starting dates varied due to differing coverage-PSYCHINFO (1940), Sociological Abstracts (1950), ProQuest Social Science Journals (1990), Worldwide Political Science Abstracts (1970). While antisemitism in general was not neglected, and many studies addressed the Holocaust, almost no research in any of the databases until 2000 covered antisemitism in the Muslim or Arab worlds. After 2000, a handful of studies appeared on the topic, though it remained largely ignored. An associated content analytic study of psychological research showed that very few psychologically based investigations of antisemitism of any kind made reference to the religious roots of the prejudice. When studies did allude to religious roots, they more often spoke of the Christian roots of Jew-hatred than of the Islamic roots. Overall, $77 \%$ of the examined psychological works made no reference at all to the religious roots of Jew-hatred. Twelve percent at least briefly noted a role for Christianity and 4\% mentioned a role for Islam. An additional 7\% alluded to religious origins of antisemitism that were either unspecified, or related to both Christianity and Islam. The coding scheme aimed at being inclusive; thus, if there had been any possible way to infer that the author of a study saw a possible religious source of the prejudice, it was scored as present. Consequently, we may conclude that relatively few authors of psychologically based studies of antisemitism saw religion as a key causal factor. Alternatively, if they did think religious causes were important, they nonetheless omitted them from their research for one reason or another.

15 See, for example, R. W. Hood, P. C. Hill, and B. Spilka, The Psychology of Religion: An Empirical Approach (New York: Guilford, 2009); M.E. Nielsen, A. T. Hatton, and M. J. Donahue, "Religiousness, Social Psychology, and Behavior," in Handbook of the Psychology of Religion and Spirituality, ed. R. F. Paloutzian and C. L. Park (New York: Guilford, 2013), 312.

16 N. J. Kressel and S. W. Kressel, "Trends in the Psychological Study of Contemporary Antisemitism: Conceptual Issues and Empirical Evidence,” Basic and Applied Social Psychology 38, no. 2 (2016): 111. 


\section{Some Preliminary Caveats}

This paper aims to clarify the relationship between Islam as a religion and Jewhatred as it currently exists in the Muslim world. As we shall see, part of this clarification involves more carefully stating the questions we are attempting to answer. So, we need to start with a few caveats.

First, and regardless of the view one ultimately takes about whether Islamic religious sources feed Jew-hatred, it is patently clear that individual Muslims may be entirely free of antisemitism. ${ }^{17}$ Many religious Muslims may not even have heard of the particular antisemitic texts and sources that antisemitism scholars find so troubling. Many have not been exposed to the hateful utterances that occur in some mosques, simply because they attend other mosques where such bigotry is not spoken or tolerated. Some have been exposed to the antisemitic ideology and-due to secular learning, skepticism, human decency, past interactions with non-believers, and many other reasons-have dismissed the hatefulness as nonsense or otherwise unacceptable. People cannot be seen as vessels who receive fourteen-hundred-year-old streaming religious traditions passively and mindlessly. It is not like Islamic civilization is downloaded by a button press into the individual. People are complex beings who derive their identities from multiple sources-their careers, their families, their neighborhoods, their schools, their friends, and the media. ${ }^{18}$ In America and other parts of the West, especially, those agents of socialization can go a long way toward erasing the effects of religion-good or bad.

Another clarification that must be made from the outset is that all religions, or-at least-most religions, have what might be called "hard passages" or "difficult verses," ones that most reasonable people would find difficult to accept at face value nowadays. ${ }^{19}$ One cannot escape the conclusion that those who have scoured the Jewish Bible, the New Testament, the Qur'an, the Book of Mormon, and other classic religious sources have been very productive in their research, finding loads of troubling passages with which believers must contend. For fair-minded, tolerant, modern, and progressive believers, the key generally is

17 D. V. Goska, “Counter-Jihad: We're About Truth, Not Hate,” Frontpage Mag, December 2015, https://www.frontpagemag.com/fpm/261187/counter-jihad-were-about-truth-not-hate-danushav-goska.

18 B. Beit-Hallahmi, Psychological Perspectives on Religion and Religiosity (New York: Routledge, 2015), 40-55.

19 N. J. Kressel, Bad Faith: The Danger of Religious Extremism (Amherst: Prometheus, 2007), 149-98. 
to disable (or weaken) these religious passages one way or another via theological reinterpretation or some other means. And this is rarely a simple task. Usually, the most dangerous scripturally based problems come from two sources-(1) the founding narrative of the faith and (2) the rules, stories, and examples that deal with treatment of those outside of the faith. If we conclude, as I shall, that Islam contains problems of this sort, we must not overlook similar problems in most other faith traditions.

Moreover, we must acknowledge that the presence of religious sources and imagery in contemporary antisemitism does not prove that the antisemitism was directly "caused" by the religious material. We must, more generally, be cautious about what some political scientists call "mystification by history," the idea that distant historical events fully explain contemporary occurrences. For example, years ago, in a discussion of ethnic cleansing in Bosnia, I noted that some people tended to explain the bloodshed as the product of hundreds of years of nonstop and "ancient" animosities. ${ }^{20}$ Such explanations tell us little about how distant historical events become psychologically relevant for contemporary individuals and sociologically and politically relevant for contemporary societies. Even if Islamic religion contributes to the genesis of current Jew-hatred in the Muslim world, it cannot be considered a sufficient explanation, and it may not be the most significant level of analysis to pursue.

At the same time, we can reject the position that Islam cannot possibly be the problem because the faith-and the Qur'an-have been around for many centuries and during nearly all of that time Jews in Islamic civilization were treated well. This argument, quite simply, fails historically. ${ }^{21}$ Some authors, like Andrew Bostom and Ibn Warraq emphasize a more or less continuous pattern of bigotry and mistreatment; others like Mark Cohen paint a rosier picture, especially in contrast with how Jews were treated by Christians in Europe. Bernard Lewis suggested that under traditional Islam, there was "normal" prejudice-sometimes more, sometimes less-but not usually obsessive until modern times. ${ }^{22}$ I think

20 N. J. Kressel, Mass Hate: The Global Rise of Genocide and Terror (New York: Plenum, 1996), 20.

21 M. Gilbert, In Ishmael's House: A History of Jews in Muslim Lands (New Haven: Yale University Press, 2010); Wistrich, Lethal Obsession; N. A. Stillman, The Jews of Arab Lands: A History and Sourcebook (Philadelphia: Jewish Publication Society, 1979); idem, The Jews of Arab Lands in Modern Times (Philadelphia: Jewish Publication Society, 1991).

22 Bostom, The Legacy of Islamic Antisemitism; I. Warraq, The Islam in Islamic Terrorism (Nashville: New English Review, 2017); M. R. Cohen, Under Crescent and Cross: The Jews in the Middle Ages (Princeton: Princeton University Press, 2008); B. Lewis, Semites and Anti-Semites (New York: Norton, 1987). 
the most reasonable position is that, under Islam (overall), Jews frequently were treated better than under Christianity until recent decades. But Christianity, after all, set a very low standard for treatment of Jews, varying from bad to intolerable to murderous. Islam created a political and religious world that sometimes included a degree of tolerance based on second-class citizenship purchased at a high price. Hatred was intensified whenever Jews, individually or politically, tried to emerge from second-class status. Violence was sometimes a feature of the Jewish condition in the world of Islam-but not always. The whole system rested on Jews acknowledging their individual and collective inferiority; if they did so, they might-sometimes-be able to live reasonably well. As Eunice Pollack recently argued, part of the reason for the popularity of the "happy dhimmis" myth is that it has proved useful to anti-Zionists. ${ }^{23}$

Finally, we should note a general tendency in some quarters to give religion a pass in explaining human misbehavior. In these circles, there is often even more unwillingness to consider the Islamic roots of misbehavior because of a belief that world peace depends on Christians and Muslims getting along and that this goal cannot be advanced through any analysis that shows Islam in negative light. Such analyses, according to some, would feed prejudice against Muslims. As Europe found out during the Thirty Years War, it can certainly be destructive to try to insist on unanimity in matters of religion, and there are very good reasons for treating other people's religious beliefs respectfully and with some sensitivity. But, in the final analysis, one cannot be allowed to plead religious belief as a shield against those who charge bigotry. To pretend that religion is irrelevant is to be blind, unwise, and dishonest.

\section{Identifying Islamic Religious Sources of Antisemitism}

Previously, I suggested that we can divide the documentation of Jew-hatred into twelve categories:

1. Antisemitic assertions by heads of state, political leaders, former political leaders, government officials, religious figures, and scholars;

2. Lack of general outrage or even significant, well-publicized challenges in response to these antisemitic assertions;

23 E. G. Pollack, "Foundation Myths of anti-Zionism," in From Antisemitism to Anti-Zionism: The Past and Present of a Lethal Ideology, ed. E. G. Pollack (Boston: Academic Studies, 2017), 245. 
3. Antisemitic articles and images in newspapers, magazines, broadcast media, and the internet;

4. Antisemitic textbooks and other instruments for socialization of the young;

5. Public opinion data showing highly prevalent negative and stereotypical attitudes toward Jews;

6. Video documentation of bigotry in very young children;

7. Terrorist targeting of Jews and Jewish institutions;

8. Vicious denunciations of Muslims who defend Jews;

9. Denunciations of all sorts of political, personal, and theological opponents as Jews, or as friends of the Jews;

10. Excerpts from religious texts-the Qur'an, the Hadith, the Sira, etc.-that plausibly appear to sustain or reinforce hostility toward Jews, coupled with anti-Jewish interpretations by contemporary religious leaders and theologians (in contrast to more moderate or tolerant interpretations);

11. Laws and organizational policies that discriminate against Jews;

12. Reports by Jews that they feel uncomfortable or unsafe practicing Judaism or displaying signs of Jewish identity in Muslim countries or regions with high percentages of Muslim residents.

Supporting documentation for each of these categories can be found in numerous works. ${ }^{24}$

Sometimes-though not in my view frequently-Muslim religious leaders, especially in Western countries, have condemned or otherwise opposed antisemitism in their communities. ${ }^{25}$ These condemnations have ranged from opposition to "racism and prejudice in all forms," which we see most commonly in comparison to "racism, prejudice, and antisemitism," which we see less commonly to specific denunciations of particular instances of Muslim Jew-hatred tied to named Muslim leaders, which we see rarely. There is also a category of Muslim religious leaders who neither support nor oppose antisemitism: bystanders, so to speak. However, if we examine the twelve categories of documentation of antisemitism in the Muslim world, we also frequently observe Islamic religious leaders taking a leading role in permitting, endorsing, supporting, and generating many forms of hostility. These religious leaders may represent a relatively small percentage of Muslim religious leaders in total, but we do not have clear data on this question.

24 See, for example, Kressel, “The Sons of Pigs and Apes”; Fatah, The Jew Is Not My Enemy; Gilbert, In Ishmael's House; Wistrich, A Lethal Obsession.

25 Kressel, "The Sons of Pigs and Apes," 188. 
What we do know is that Islamic clerics are the source of a large percentage of the most virulent antisemitic utterances found in the mass media and on the internet. They frequently deliver antisemitic speeches and pen antisemitic writings. They also contribute to the antisemitic socialization of the young through sermons and religious education. Denunciations of those who defend Jews often are made by those who possess religious credentials, and denunciations are justified on religious grounds. Many antisemitic events take place in mosques. Moreover, the vast majority of Muslim religious leaders-even those who speak out against terrorism-remain quiet when confronted by evidence of bigotry in their community. So, in this sense, the Islamic religion certainly plays a role in sustaining antisemitic sentiments and activities.

However, it is certainly possible that religious leaders themselves derive their prejudice from sources outside of Islam. Some scholars have gathered evidence suggesting that a good deal of antisemitism in the Muslim world seems pretty clearly to have been imported from Europe in the twentieth century and even earlier. ${ }^{26}$ The Muslim clerics who feed contemporary antisemitism could be deriving their ideology partly from this colonial heritage of imported bigotry, not to mention from their anger (whether justified or not) toward Israel.

The case for a deeper Islamic involvement in the genesis of antisemitism requires us to review specific sources of hostility toward Jews in the Islamic religious tradition. Unfortunately, such sources are not hard to find. He was exaggerating to achieve his objectives, but the Grand Mufti Amin el-Husseini in 1944 was able to tell Bosnian troops fighting for the Nazis in World War II-"Nearly onethird of the Qur'an concerns the Jews. The Qur'an calls upon all Muslims to protect themselves against the Jews and to fight them wherever they may meet."27

Many Islamic texts concern Jews. A full analysis of the Qur'anic and other Islamic religious references to Jews is not possible here, but it should be made clear that not all such references are unequivocally negative. Although Islam at its core has the notion of Jews and Christians having mishandled their religious obligations, Muhammad at times expressed somewhat positive thoughts about aspects of Judaism and Christianity, and the Islamic religious system put Jews and Christians in a different, more protected category from other non-believers. Reviews of Islamic religious materials by Bostom and Ibn Warraq, while useful, are highly polemical and do not show how texts might be interpret-

26 J. Herf, Nazi Propaganda for the Arab World (New Haven: Yale University Press, 2009); M. Küntzel, Jihad and Jew-hatred: Islamism, Nazism and the Roots of 9/11, trans. C. Meade (Candor: Telos, 2007); B. Rubin and W. G. Schwanitz, Nazis, Islamists, and the Making of the Modern Middle East (New Haven: Yale University Press, 2014); Lewis, Semites and Anti-Semites.

27 Quoted in Warraq, The Islam in Islamic Terrorism, 291. 
ed with less antisemitic potential. ${ }^{28}$ It is probably more accurate to say that tolerance and intolerance coexisted within the same tradition. To sort all this out systematically lies beyond the scope of this essay.

But, without question, the Islamic religious tradition contains many sources that are ready for use by contemporary antisemites. In each instance, the progressive or moderate Muslim is probably able to interpret, reinterpret, or adapt the tradition in a way that renders its less useful for the antisemite. On the other hand, it is rarely clear that the moderate interpretation is the more textually accurate or historically plausible one.

Three aspects of the Islamic tradition are especially troubling:

- Events in the Seventh Century as Reported in the Qur'an, the Sira, and the Hadith. All surviving accounts of Muhammad's conflicts with the Jews come from the religious sources of one side. Thus, there is no definitive historical evidence about what actually transpired in the seventh century. For example, did any Jews actually break treaties with Muhammad? If so, did they have good reasons to do so? Did the Muslims break any treaties with the Jews? Did the frequently cited story of sexual harassment of a Muslim woman by a Jew in a marketplace really happen? Who knows? But historical truth, by now, has become largely irrelevant. Tales of Jews as deceivers, treaty violators, falsifiers of sacred books, Sabbath violators who were transformed into pigs and apes, and more have roots that can be traced back to the Qur'an and other early religious sources. Jews are blamed for rejecting Jesus and for poisoning Muhammad's food, a deed sometimes cited as a contributing factor to his death years later. Some of these stories involve particular Jews, or groups of Jews; few are aimed at the entire Jewish people. But the Muslim religious tradition, at the very least, shows Jews as people who rejected the great teacher's ideas and were defeated by him in battle.

- Later Spins on Muhammad's Conflict with the Jews. Tarek Fatah has made a case that certain parties in the early centuries after Muhammad's death, notably the then-powerful descendants of the Meccans who had rejected $\mathrm{Mu}$ hammad, had reason to portray the Jews as his greatest enemies. ${ }^{29}$ Thus, some hadiths (which may have been inauthentic) may have greatly reinforced the anti-Jewish aspects of Muhammad's era, even creating for him a role that he may never have played in presiding over the massacre of the unarmed tribe of Banu Qurayza Jews. According to Fatah, the worst antisemitism in the early Islamic tradition may have been fabricated. But

28 Bostom, The Legacy of Islamic Antisemitism; Warraq, The Islam in Islamic Terrorism. 29 Fatah, The Jew Is Not My Enemy, 134. 
it should be pointed out that-Fatah's fascinating arguments notwithstanding-most observant Muslims regard Muhammad's murder/punishment of the Banu Qurayza Jews as an historical event. It is hard to know whether Fatah's argument is correct or merely wishful thinking, but his heart is in the right place. On the other hand, many Muslim's accept as truth that Muhammad was willing to wipe out an entire tribe of Jews-hardly a happy precedent.

- $\quad$ The Long Muslim Political and Religious Tradition of Discrimination and Prejudice. The Islamic religious tradition, like other religious traditions, had an element of contempt for non-believers, although this negative sentiment usually did not rise to the level of hate or obsession observed in the Christian world. Still, institutionalized discrimination, a sense of superiority, and various restrictions on free religious practice were rarely missing over many centuries. It remains a matter of debate just how widespread, intolerable, and injurious various anti-Jewish measures were. It also remains a matter of historical debate whether the Christian experience of life under Islam was better, worse, or the same as the Jewish experience.

Indigenous religious traditions made the Islamic world especially receptive to new, sometimes more intense and obsessive, antisemitic ideas that accompanied the European colonialists. When Christian missionaries and later secular antisemites told stories of blood libels and Jewish conspiratorial plots, Muslims had been prepared by Islam to accept such ideas uncritically-even enthusiastically. Nazis, later on, were somewhat successful in recruiting Muslims partly because of the indigenous religious foundations of Jew-hatred. Islam prepared the ground for Jew-hatred in a way not entirely different from how Christianity laid the soil for later non-Christian antisemitism to grow.

The Islamist perspective on the faith had been developing gradually over many years, starting all the way back with Wahhabi movement in eighteenthcentury Arabia. The Salafi approach, which emphasized a spiritual return to the early days of Islam, brought additional focus on Muhammad's negative interactions with Jews. The Muslim Brotherhood movement, founded in Egypt in 1928 by Hassan al-Banna, grew increasingly anti-Jewish during World War II (in part through its connection to the virulently antisemitic Grand Mufti). Sayyid Qutb perhaps brought antisemitism to its ideological fruition in his mid-century works; as Qutb's extremist approach was accepted by more and more Muslims, antisemitism spread with it. Islamists could only make their case because of the pre-existing Islamic foundation for Jew-hatred.

At various times in Islamic history, anti-Jewish elements of the tradition loomed more or less large. When the Jews were weak and without a state, and 
Islam was thriving, the old seventh-century enemies could be viewed as naturally subordinate. And so some of the antisemitic traditions at other times receded into history, occasionally mentioned but not-as Lewis noted-the basis for obsessive hatred. ${ }^{30}$ With the emergence of Israel, and the Muslim world (for many reasons) in sociopolitical disarray, the old texts were dusted off.

As I have argued elsewhere, the great hostility toward Israel may in fact have a religious element at its core. ${ }^{31}$ The late psychoanalyst Mortimer Ostow explained the situation well. He wrote, that:

The obvious source of current Arab and Muslim resentment against the Jews derives from the establishment of the State of Israel in 1948 on land claimed by the Muslim Arabs. . . . But the Jews also represented a mythic enemy, a principle of cosmic evil. It was only because of that satanic power, the Arabs argued, that they were able to defeat the Arab armies which had come to wipe them out in recent years. Throughout the history of Jewish-Muslim coexistence in Muslim countries, both Jews and Christians were tolerated only as long as they acknowledged the subservient status to which they were assigned, and which they accepted. That the Jew, who, in Muslim eyes, was seen as weak, cowardly and ineffectual, could impose such a quick and definitive military defeat upon the Arab enemy could not be explained except by the theory that the Jews embodied a principle of cosmic evil, a satanic element, whose worldwide conspiracies would some day be disclosed and defeated..$^{32}$

This, I think, is the main engine behind contemporary Arab and Muslim antisemitism. It is the deepest reason why the Arab-Israeli conflict has been so difficult to resolve. Conflicts over land can be negotiated. Peace with Israel almost certainly would bring huge economic and political dividends first and foremost to the Palestinians. The problem is that peace might extract a psychological, and perhaps theological, cost that would be difficult to bear. Jews as equals is bad enough, a violation of the religious order in which they are supposed to behave as dhimmis. But Jews who prevail in fair competition would be a bad reflection on the faith, the culture, and by extension, the self.

One can, to some extent, work through inconsistencies between political reality and what Muslims expect from their religious ideology by holding that Jews are, as the religious sources taught, godless, evil, tricky and, as the imported Protocols taught, involved in a massive plot to control the world, possessing power over the United States and just about everyone else. One might also get some re-

30 Lewis, Semites and Anti-Semites, 21.

31 Kressel, "The Sons of Pigs and Apes," 169-70.

32 M. Ostow, "Commentary on "Mass Hatred in the Muslim and Arab World: The Neglected Problem of Anti-Semitism by Neil Kressel," International Journal of Applied Psychoanalytic Studies 4, no. 3 (2007): 229-30. See, also, idem, Myth and Madness: The Psychodynamics of Antisemitism (New Brunswick: Transaction, 1996). 
lief by maintaining that corrupt leaders betrayed the Muslims. With beliefs such as these, the crumbling yet psychologically important edifice can be buttressed. Such mental manipulations end up reducing the unpleasant psychological dissonance and restoring some tranquility. ${ }^{33}$

\section{Conclusion}

While it would be an immensely complicated task to specify the precise social psychological mechanisms through which Islamic anti-Jewish tenets become relevant in the generation and maintenance of antisemitic beliefs and behaviors in the contemporary lives of individuals, it is a fairly straightforward matter to outline the major pathways of this influence.

- The historical tradition of antisemitism can legitimize and render more plausible all arguments and positions that involve Jew-hatred, whatever their source.

- A call to oppose the Jews may most immediately stem from exposure, say, to a television program based on the imported Protocols of the Elders of Zion; yet that program may be popular precisely because it reinforces indigenous religious messages.

- Jews may become scapegoats for frustrations that originate in contemporary economic, political, sociological, or personal problems; however, their selection as the scapegoats of choice may be the product, in part, of their traditional portrayal as deceptive, dishonorable, and murderous in some Islamic religious sources.

- The inability to find a reasonable resolution to the Israeli-Arab conflict may indeed feed the fires of Jew-hatred. However, the difficulties in solving this conflict may, themselves, arise from religious expectations about the proper role for Jews in the Islamic world, along with the religious notion that land which has been ruled by Muslims cannot ever fall under the rule of other groups.

- Children may become antisemites because of the socialization processes they experience while under the influence of imams who have been radicalized. The ideologies they absorb may not represent "true" Islam as defined by moderates. But these extremist imams are still part of the religious tradition, and their positions derive plausibility from the existence of real precedents in the religious tradition.

33 This argument is developed in greater detail in Kressel, "The Sons of Pigs and Apes," 169-70. 
- The more one takes the religious tradition seriously, the more its anti-Jewish elements become relevant, though religiosity may also lead one to examine the countervailing tenets of tolerance as well. On the other hand, abandonment of the religious tradition does not mean that one has become free of Islam's potential to legitimize hostility to Jews.

- $\quad$ Those who oppose antisemitism may be rendered less effective by portraying them, not implausibly, as out of touch with the views that prevail in the Hadith, the Sira, and elsewhere.

When the roots of prejudice lie within a religious tradition that helps more than a billion people to cope with their existential issues and to achieve an overall sense of meaning in life, there is certainly a basis for pessimism. But perhaps the greatest reason for optimism lies in the recognition that the Christian religious tradition contains at least as strong, and arguably a considerably stronger, basis for Jew-hatred. And yet many Christians in the twentieth century went very far toward removing, weakening, and rendering inoperable (at least, temporarily) these antisocial elements of the faith. An analysis of currently prevailing theological and political trends does not suggest that a similar process of prosocial reinterpretation is likely in the mainstream Islamic religious community. But it is, at least, possible that current progressive efforts originating outside of that mainstream might over time gain more adherents.

Where do we stand now? If we ask, is Islam eternally, irredeemably, and incurably hostile to Jews, the answer is no. And if we ask, is Islam different at its core from other major faith traditions in preaching hostility to certain nonbelievers, the answer-I think-is also no. If we were to probe the sacred texts of Judaism (and Christianity), would we find a large number of difficult, morally challenging passages? Absolutely. Do individual Muslims necessarily derive from their religious tradition beliefs that predispose them to become antisemites? Again, I think not. Individuals have complex identities and belief systems; they are not passive recipients of everything in their faith's tradition. Are some Muslim religious leaders speaking out forthrightly and effectively against the antisemitic potential of Islam? Definitely, some-but not many. Are religious Muslims more likely to be antisemitic than non-religious people from Muslim backgrounds? This seems an empirical question for which we have only sketchy answers. Do Jews have anything to worry about with increasing immigration of Muslims into the West? This one is tricky. I think the answer is yes, Jews should be concerned. But I'm not sure what political and policy implications should follow from this concern. Can interfaith programs with Muslim leaders be a useful way to improve relations? Yes, probably, but only if such programs are open and honest about antisemitism when it occurs. Does Islam need an en- 
counter with its antisemitic past similar to that which the Catholic Church and other Christian denominations had in the mid-twentieth century. Yes. Is this likely to happen? Not as far as I can tell.

Neil J. Kressel is Professor of Psychology and Director of the Honors Program in the Social Sciences at William Paterson University. His books include: "The Sons of Pigs and Apes": Muslim Antisemitism and the Conspiracy of Silence, Bad Faith: The Danger of Religious Extremism, and Mass Hate: The Global Rise of Genocide and Terror. He is currently completing a textbook on the psychology of religion.

\section{References}

Allport, Gordon W. The Nature of Prejudice. Cambridge: Addison-Wesley, 1979.

Allport, Gordon W., and J. Michael Ross. "Personal Religious Orientation and Prejudice." Journal of Personality and Social Psychology 5, no. 4 (1967): 432-43.

Bali, Rifat N. "Conspiracy Theories, Antisemitism and Jews in Turkey Today." In Global Antisemitism: A Crisis of Modernity, vol. 4, Islamism and the Arab World, edited by Charles Asher Small, 47-54. New York: ISGAP, 2013.

Beit-Hallahmi, Benjamin. Psychological Perspectives on Religion and Religiosity. New York: Routledge, 2015.

Bostom, Andrew G. Iran's Final Solution for Israel: The Legacy of Jihad and Shi'ite Islamic Jew-Hatred in Iran. Washington: Bravura Books, 2014.

Bostom, Andrew G. The Legacy of Islamic Antisemitism: From Sacred Texts to Solemn History. Amherst: Prometheus Books, 2008.

Bunzl, Matti. Anti-Semitism and Islamophobia: Hatreds Old and New in Europe. Chicago: Prickly Paradigm, 2007.

Butler, Judith. "Foreword." In On Anti-Semitism: Solidarity and the Struggle for Justice, edited by Jewish Voice for Peace. Chicago: Haymarket Books, 2017.

Cohen, James. "The Accusation of Anti-Semitism as Moral Blackmail: Conservative Jews in France and the Israel-Palestinian Conflict." Human Architecture 7, no. 2 (2009): 23-33.

Cohen, Mark R. Under Crescent and Cross: The Jews in the Middle Ages. Princeton: Princeton University Press, 2008.

Cohen, Nick. What's Left?: How Liberals Lost Their Way. New York: Harper Perennial, 2007.

Fatah, Tarek. The Jew is Not My Enemy: Unveiling the Myths that Fuel Muslim Anti-Semitism. Plattsburgh: McClelland \& Stewart, 2011.

Gilbert, Martin. In Ishmael's House: A History of Jews in Muslim Lands. New Haven: Yale University Press, 2010.

Glock, Charles Young, and Rodney Stark. Christian Beliefs and Anti-Semitism. New York: Harper \& Row, 1966.

Goska, Danusha V. “Counter-Jihad: We're about Truth, not Hate: Eight Leading Counter-Jihad Activists Speak Out." Frontpage Mag, December 22, 2015. https://www.frontpagemag. com/fpm/261187/counter-jihad-were-about-truth-not-hate-danusha-v-goska. 
Harrison, Bernard. The Resurgence of Anti-Semitism: Jews, Israel, and Liberal Opinion.

Lanham: Rowman \& Littlefield, 2006.

Herf, Jeffrey. Nazi Propaganda for the Arab World. New Haven: Yale University Press, 2009.

Hirsh, David. "Anti-Zionism and Antisemitism: Cosmopolitan Reflections." In The Yale Papers:

Antisemitism in Comparative Perspective, edited by Charles Asher Small, 57-174. New York: ISGAP, 2015.

Hood, Ralph W., Peter C. Hill, and Bernard Spilka. The Psychology of Religion: An Empirical

Approach. New York: Guilford, 2009.

Ibn Warraq. The Islam in Islamic Terrorism. Nashville: New English Review, 2017.

Jaspal, Rusi. Antisemitism and Anti-Zionism: Representation, Cognition, and Everyday Talk. Farnham: Ashgate, 2014.

Jikeli, Günther. European Muslim Antisemitism: Why Young Urban Males Say They Don't Like Jews. Bloomington: Indiana University Press, 2015.

Kressel, Neil J. Bad Faith: The Danger of Religious Extremism. Amherst: Prometheus Books, 2007.

Kressel, Neil J. "The Great Failure of the Anti-Racist Community: The Neglect of Muslim Antisemitism in English-Language Courses, Textbooks, and Research." In From Antisemitism to Anti-Zionism: The Past and Present of a Lethal Ideology, edited by Eunice G. Pollack, 29-68. Boston: Academic Studies, 2017.

Kressel, Neil J. Mass Hate: The Global Rise of Genocide and Terror. New York: Plenum, 1996. Kressel, Neil J. "The Sons of Pigs and Apes": Muslim Antisemitism and the Conspiracy of Silence. Washington: Potomac Books, 2012.

Kressel, Neil J. and Samuel W. Kressel. "Trends in the Psychological Study of Contemporary Antisemitism: Conceptual Issues and Empirical Evidence." Basic and Applied Social Psychology 38, no. 2 (2016): 111-26.

Küntzel, Matthias. Jihad and Jew-Hatred: Islamism, Nazism and the Roots of 9/11. Translated by C. Meade. New York: Telos, 2007.

Lewis, Bernard. Semites and Anti-Semites. New York: Norton, 1987.

Mearsheimer, John J. and Stephen M. Walt. The Israel Lobby and U.S. Foreign Policy. New York: Farrar, Straus and Giroux, 2008.

N. N. "California Friday Sermon: Imam Ammar Shahin Cites Antisemitic Hadith, Prays for Annihilation of Jews, and Calls to Liberate Al-Aqsa Mosque from their 'Filth'." MEMRI TV clip no. 6133. July 21, 2017. https://www.memri.org/tv/california-sermon-antisemitic-ser mon-kill-jews-liberate-al-aqsa-mosque.

N. N. “Friday Sermon at Jersey City, NJ." MEMRI TV clip no. 6310. December 8, 2017. https:// www.memri.org/tv/antisemitic-sermon-jersey-city-imam-aymen-elkasaby.

N. N. "Friday Sermon in the Raleigh Area, NC, by Syrian Imam Abdullah Khadra." MEMRI TV clip no. 6361. December 8, 2017. https://www.memri.org/tv/north-carolina-antisemiticsermon-abdullah-khadra-haifa-acre-jaffa-muslim-land.

N. N. “Gaza Friday Sermon by Hamas MP Marwan Abu Ras.” MEMRI TV clip no. 5846. January 6, 2017. https://www.memri.org/tv/gaza-friday-sermon-hamas-mp-marwan-abu-ras-jewsrecruit-prostitutes-girls-aids-lure-arabs-their.

N. N. "Saudi Cleric Mamdouh Al-Harbi." MEMRI TV clip no. 6162. July 26, 2017. https://www. memri.org/tv/saudi-cleric-muslim-war-with-jews-not-just-zionists. 
N. N. "Sudanese Imam Responds to Call for Normalization of Ties with Israel." MEMRI TV clip no. 5949. February 16, 2017. https://www.memri.org/tv/sudanese-imam-responds-callnormalization-ties-israel-muslims-enmity-towards-brothers-pigs-and.

Nielsen, Michael E., Arthur T. Hatton, and M. J. Donahue. "Religiousness, Social Psychology, and Behavior." In Handbook of the Psychology of Religion and Spirituality, edited by Raymond F. Paloutzian and Crystal L. Park, 312-29. New York: Guilford, 2013.

Ostow, Mortimer. "Commentary on 'Mass Hatred in the Muslim and Arab World: The Neglected Problem of Anti-Semitism' by Neil Kressel.” International Journal of Applied Psychoanalytic Studies 4, no. 3 (2007): 221-34.

Ostow, Mortimer. Myth and Madness: The Psychodynamics of Antisemitism. Piscataway: Transaction, 1996.

Pink, Aiden. "Arrest Warrant Issued for Imam Who Called for Jews to be Killed." Forward, July 16, 2017. https://forward.com/fast-forward/377144/arrest-warrant-issued-for-imam-whocalled-for-jews-to-be-killed/.

Pollack, Eunice G. "Foundation Myths of Anti-Zionism." In From Antisemitism to Anti-Zionism: The Past and Present of a Lethal Ideology, edited by Eunice G. Pollack, 227-64. Boston: Academic Studies, 2017.

Rubin, Barry M., and Wolfgang G. Schwanitz. Nazis, Islamists, and the Making of the Modern Middle East. New Haven: Yale University Press, 2014.

Stillman, Norman A. The Jews of Arab Lands. Philadelphia: Jewish Publication Society, 1979.

Stillman, Norman A. The Jews of Arab Lands in Modern Times. Philadelphia: Jewish Publication Society, 1991.

Wistrich, Robert S. A Lethal Obsession: Anti-Semitism from Antiquity to the Global Jihad. New York: Random House, 2010.

Yaqeen Institute for Islamic Research. "The Hadith and the Myth of an Antisemitic Genocide in Muslim Scripture.” Huffington Post, March 28, 2017. https://www.huffpost.com/entry/ the-jew-killing-hadith-and-the-myth-of-an-antisemitic_b_58da7e56e4b0e96354656eb6. 
